\title{
Active Search for Perpetrators of Most Serious Criminal Offences - the Croatian Model
}

\author{
Goran Žaja ${ }^{1}$, Dean Savić ${ }^{2}$, Marijo Rošić ${ }^{3}$ and KSenija Butorac ${ }^{4 *}$ \\ ${ }^{1}$ Head of the Fugitive Unit - FAST Croatia, Special Criminal Investigations Department, Europe \\ ${ }^{2}$ Head of the Organized Crime Department, Police National Office for Suppression of Corruption and Organized Crime, Europe \\ ${ }^{3}$ Head of the International Police Cooperation Department, Criminal Police Directorate, Europe \\ ${ }^{4}$ Police College, Ministry of the Interior, Europe
}

Submission: September 01, 2017; Published: September 11, 2017

*Corresponding author: Ksenija Butorac, Associate Professor, Police College, Ministry of the Interior, Zagreb 10000, Croatia, European Union, Europe, Email: kbutorac@mup.hr

\begin{abstract}
Number of cases in which search for perpetrators is conducted is on the rise. Conditions in which borders are open and free flow of people, goods and capital is allowed are favored by fugitives. They keep up with the times and keep track of new developments in technology. This requires adaptation of work methodology of competent services whose search for the perpetrators of criminal offences represents one of their fundamental obligations. When doing so, it is necessary to acquire new knowledge and develop tactical, technical and human capacities in a timely matter. Croatian police follows current trends and is on a good path to satisfy actual needs and to achieve maximum success in the area of active search for perpetrators of most serious criminal offences. The Fugitives Unit was founded in 2008 - a unit dedicated to search for fugitives and which operates within the Police National Office for Suppression of Corruption and Organized Crime. Since 2012, the SIReNE Section has been operational within the International Police Cooperation Service of the Criminal Police Directorate ${ }^{1}$ as the central point for searches in cases where the SIS II System is used. Since 27th June 2017, all searches in the second-generation Schengen Information System (SIS. II) of the Schengen Area member countries have been available to the Republic of Croatia. Since that day Croatian authorities have also had the possibility of issuing their own searches within the SIS II System. Complementary work of the Fugitives Unit and the SIReNE Section created the preconditions for quality and coordinated proceedings when undertaking measures for fugitive active search.
\end{abstract}

Keywords: Fast; Enfast; Interpol; Sirene; International search; Fugitive active search

\section{Introduction}

Open borders, liberal control regime and science and technology development allow for quick flow of people, goods and capital. Such circumstances also favor crime mobility, which hinders undertaking of fugitive active search measures. Favorable conditions regarding freedom of movement facilitate achievement of criminal goals for individuals and organized crime groups, as well as allow them to achieve maximum illegal gain. One of the consequences of such situation is an increase of the number of criminal proceedings which have been conducted in absentia of accused persons. Thanks to the aforementioned conditions, perpetrators of criminal offences easily change home addresses and thus areas of operation. Likewise, after committing a criminal offence, their crossing from one country to another is facilitated.

This significantly hinders their identification, location and arrest, making this one of more important reasons why an increasing number of perpetrators at large is being registered.
Therefore, the number of issued warrants is also growing, as well as the number of initiated or finished criminal proceedings with the accused in absentia. On the other hand, activities related to locating fugitives have not always been on a level that was wanted. Some of the reasons for reduced efficiency were the result of obstacles due to inadequate legal and financial frameworks. To deal with these obstacles, a full set of international and national legal acts was adopted. Following this, rising number of countries began forming various forms of specialised units that, among other things, deal with target searches for perpetrators of criminal offences. Activities of those units hold a significant place in combating crime. Searching for fugitives is a complex operational process which requires implementation of a number of measures and actions, especially for cases when a search is performed in several countries. Special investigation techniques may be used for this. Regarding this, it is necessary to react to changes in modus operandi of fugitives or persons preparing to flee, both on operational and normative level. This includes 
timely initiative for legislative changes and changes of other regulations in accordance with identified changes in modus operandi of persons fleeing from criminal prosecution. Likewise, focus and creativity in creating, exchanging and application of the best practical solutions which were gained during a search for fugitives is very important.

At this point, it is necessary to point out that, in the near future, entering into the Schengen Area shall represent a special security challenge for the Republic of Croatia considering that the border with EU member states (Hungary and Slovenia landwise and Italy at the sea) shall be left without systematic border control. Compensational measures that will be implemented will probably be less effective than systematic controls at external borders. This will additionally facilitate movement of persons fleeing from the law.

Hereinafter a description will be provided regarding some innovative solutions used during searches for fugitives in EU countries and further. Experiences so far point to a need for frequent implementation of these solutions, especially in international searches with the application of special investigation techniques. Specialised units for fugitive active search and their cooperation with central bodies in charge of coordinating operations in international searches play a key role in this ${ }^{2}$.

\section{International Search Instruments}

There are two instruments for international search for fugitives wanted for arrest being implemented on international level. After exhausting search measures for persons on national level, it is possible to issue an international search. One such search instrument is INTERPOL Red Notice, whose purpose is to make an arrest for extradition, and the second one is the European arrest warrant, a specific instrument on Schengen level that is issued via the SIS II System. The second one has shown to be much quicker and efficient in comparison with Red Notice. Both instruments are issued on the basis of a fugitive search warrant issued by the judicial bodies in written form.

By entering the European Union on the 1 July 2013, the Republic of Croatia started implementing the Framework Decision on European arrest warrant by implementing the Act on Judicial Cooperation in Criminal Matters between the Member States of the European Union (cro.Zakon o pravosudnoj suradnju u kaznenim stvarima s državama članicama Europske unije) The procedure of arrest based on the so-called Red Notice is noted terminologically as "extradition" and is defined in the Croatian legal system by the Act on International Legal Assistance in Criminal Matters (cro. Zakono međunarodnoj pravnoj pomoći u kaznenim stvarima). The procedure of realization of the European arrest warrant is noted terminologically as the procedure of "surrender" and is defined by the aforementioned Act on Judicial Cooperation in Criminal Matters between the Member States of the European Union.

Application of the European arrest warrant (EAW) has resulted in an increase of the total number of arrests, as seen in (Table 1). In 2014 there were 201 arrests in total, while in 2013, before EAW started being implemented in full in the Republic of Croatia $^{3}$ there were 132. The proportion of surrenders, i.e. of arrests, on the basis of the European arrest warrant is predominant in the total number of arrests and is significantly higher than the number of extraditions made on the basis of INTERPOL Red Notice. This is a result of the fact that, in the case of locating a person on the basis of Red Notice, if the country of issuance is implementing the European arrest warrant then that country is asked to deliver this warrant because it makes the procedure more expedient and efficient.

Table 1: Number of extraditions, deliveries and transfers in the Republic of Croatia for a ten-year period.

\begin{tabular}{|c|c|c|c|c|c|c|c|c|c|c|}
\hline & $\mathbf{2 0 0 7}$ & $\mathbf{2 0 0 8}$ & $\mathbf{2 0 0 9}$ & $\mathbf{2 0 1 0}$ & $\mathbf{2 0 1 1}$ & $\mathbf{2 0 1 2}$ & $\mathbf{2 0 1 3}$ & $\mathbf{2 0 1 4}$ & $\mathbf{2 0 1 5}$ & $\mathbf{2 0 1 6}$ \\
\hline Extraditions & 83 & 68 & 94 & 89 & 134 & 119 & 122 & 69 & 68 & 60 \\
\hline Surrenders & & & & & & & & 109 & 133 & 124 \\
\hline Transfers & 14 & 21 & 13 & 12 & 9 & 18 & 10 & 23 & 23 & 23 \\
\hline Total & 97 & 89 & 107 & 101 & 143 & 137 & 132 & 201 & 224 & 207 \\
\hline
\end{tabular}

Source: International Police Cooperation Department statistics.

The basic difference in acting upon these instruments is that the final decision on issuance for the European arrest warrant is made by the court, while the minister of justice makes the one for INTERPOL Red Notice. Furthermore, the deadline for the submission from the day of final decision is shorter: 10 days for the EAW and 2 months for Red Notice. Also, the procedure of appealing the decisions in the surrender procedure based on the EAW is limited to clearly defined reasons. Likewise, the European arrest warrant allows for surrender of one's own citizens, which, as a rule, is not possible in case of arrest based on INTERPOL
Red Notice (except in exceptional cases when it is regulated by international agreements) (Table 1).

\section{INTERPOL instruments of search for persons}

The Red Notice represents the first available and oldest international instrument that was available to the police in their search for persons. INTERPOL issues eight different types of notices marked with special colors. Two types of red notifications are issued in relation to searching for fugitives with the aim to arrest and extradite: for individuals sought for 
criminal prosecution and those who were convicted and are expected to serve a sentence.

The Red Notice is valid in countries who are INTERPOL members. This notice is also used by EU member states in relation to third countries. Basis for its issuance is the existence of national arrest warrant and it is recognised as the only universal instrument of this kind. It is issued in INTERPOL system I-24/7 after which it becomes visible to all member countries. Exceptionally, some countries can challenge entry into force for certain Red Notices on the basis of special resolutions.

Besides the Red Notices which are issued with the purpose of arrest in order for extradition, there is also so-called Blue and Green INTERPOL Notices which may be extremely useful in locating fugitives. INTERPOL Blue Notices are issued for individuals on whom additional information is required. This can refer to perpetrators of criminal offences on which there is not enough information in order for Red Notices to be issued, potential witnesses, injured parties and other persons. INTERPOL Green Notices are issued for persons who are known as perpetrators of criminal offences in three or more countries.

INTERPOL Red Notice should be observed complementary, in regard to European arrest warrants. It is important to point out that the EAW always has precedence over INTERPOL Red Notice. For example, if both EAW and INTERPOL Red Notice are issued for a criminal offence with the same factual description, precedence in proceeding goes to that search for which an EAW was issued. Since 27 June 2017 all EAWs of Schengen Area member countries, but also data on persons or objects which are being searched in order to conduct discrete checks ${ }^{4}$ as well as data on witnesses and persons who were obligated to report to court of law, are available to the Croatian police and are integrated into a single search system. This system is available to police officers on all border crossings and in hinterland. The system of single check by defined parameters has achieved a significant stride in locating fugitives through regular field police work. The plan is to further upgrade the system by adding a possibility of comparing biometric data for wanted persons and by checking for concordance with the search data of all Schengen Area members.

\section{European Arrest Warrant and the SIS II System}

By terminating EU internal borders' surveillance, a need for tighter cross-border cooperation in combating international crime has appeared. One of more important instruments in this domain is the European arrest warrant. Its legal basis is woven into the Treaty on European Union, in the part referring to police and judicial cooperation. Decision on the European arrest warrant was adopted on 13 June 2002, and it entered into force on 1 January 2004 for member states which were obligated to implement it into their national legislation. This instrument is implemented on the entire EU territory. The purpose of introducing the European arrest warrant was to accelerate lengthy extradition procedures. It represents a new, more efficient manner of surrender of a suspect or convicted persons who fled to another member state territory within the EU. Its practical application reflects mutual trust and cooperation of competent bodies responsible for ensuring the rule of law.

This means, inter alia, respecting the principle of mutual recognition of court judgements and their easier and faster implementation in another state, i.e. the substitution of the extradition procedure with the surrender procedure to competent judicial bodies. As

Previously mentioned, the European arrest warrant offers several options in regard to INTERPOL Red Notice.

a) a simplified procedure

b) decision implemented by judicial authorities after certain conditions are met

c) European arrest warrant contains a search warrant, request for arrest, request for ordering custody and a request for surrender.

d) shortening of the extradition procedure and faster procedures by setting up deadlines for decisions and surrender of the person

e) a catalogue of criminal offences for which this warrant can be issued and implemented

f) abolishing political influence when making the final decision on surrender

g) possibility of surrendering one's own citizens

h) ensuring the balance between efficiency and human rights protection

i) less possibility of rejection of the European arrest warrant, i.e. its implementation

The European arrest warrants are registered, as mentioned earlier, as warnings in the second-generation Schengen Information System (SIS II) ${ }^{5}$. The country that is issuing EAW is responsible for its accuracy and promptness or its suspense in the SIS II System. There is currently a bit less than 30000 of them in the system. Transfer of foreign warrants into the Croatian police search registers, as well as transfer of domestic EAWs into SIS II was completed on 27 June 2017. Considering its size, Croatia has entered a sizeable number of European arrest warrants into the system: around 1400 of them.

It means practically that since 27 June 2017 all searches for persons and objects in the SIS II System of all Schengen Area members have become available to the Croatian police. Here we should highlight the fact that the highest number of entries, exits and transits through the Croatian national territory occurs right before the tourist season. During that period, provisions on the need for implementation of systematic checks at the external 
border are in force ${ }^{6}$. In conditions where Croatia is not a part of the Schengen Area, each of our border crossings towards the EU represents the EU external border. Therefore, as expected, we have experienced a large number of registered "hits"7 in regard to entries that are in the SIS II System. The International Police Cooperation Department, from the SIReNE Division, as the central unit on national level for dealing with searches in SIS II oversees acting upon all hits and data exchange in relation to these hits.

Only a few weeks' worth of experience of full implementation and acting upon searches in the SIS II System ${ }^{8}$ point to a large quantity of useful information that is registered and may, sooner or later, contribute to locating fugitives. Namely, besides the European arrest warrants, the SIS II System contains warnings regarding persons that need locating in order to participate in court proceedings, persons that require discrete checks, and notifications on missing persons and objects that are linked to persons who are searched for on any basis.

Regarding the actions of the SIReNE national office, their partner relationship with FAST is important. Their actions must be coordinated as much as possible, which is in line with European practice. It is necessary to point out that international cooperation of FAST teams cannot replace warning in the SIS II System. Furthermore, cooperation of FAST teams must not overlap with the role that SIReNE offices play, as central search points by using the SIS II System. Cooperation between FAST teams and SIReNE offices should be established in a way that FAST teams inform SIReNE offices about all current operations regarding warnings that are in the SIS II System. Every coordinated operation of the European Network of Fast Active Search Teams (ENFAST) which includes the cooperation of SIReNE offices needs to be announced to the aforementioned office. On the other hand, SIReNE offices are obligated to ensure fast supplementary information flow to FAST teams in cases of targeted search for persons.

\section{European Network of Fugitive Search Teams}

Searching for fugitives is especially important for successful conduct of criminal proceedings or for implementing criminal sanctions. Despite fast development, modern technologies and communication improvements, searching for fugitives is connected to many difficulties. New methods used by fugitives in order to avoid criminal prosecution present big challenges for the police and judicial bodies. Fugitives are mobile and can change their location fast, with borders not being a severe problem for them. Therefore, successful search demands an interdisciplinary approach. Their successful locating requires quick and direct international cooperation.

During 2010 when Belgium held the EU Presidency, the idea about forming police national units for fugitive active search (FAST-Fast Active Search Teams) and the European Network of Fast Active Search Teams (ENFAST) was presented. In countries where there were no conditions for forming such organizational units, formation of contact points for fugitive active search was suggested. The intent was to achieve a better and more efficient cooperation within the EU in the process of searching for persons. The European arrest warrant served as legal framework for functioning of FAST teams.

Decision on establishing ENFAST network was based on the need for efficient cooperation and fast information and experience exchange in the fugitive search domain. The network is designed as to ensure the possibility of quick reaction, at any time during day or night. Direct cooperation of national units is allowed, making this network one of a kind. Team members are experts in areas they deal with, and network functioning was supposed to contribute to a higher level of safety in the EU. In order for ENFAST to be actually implemented, the ENFAST Statute was adopted in 2010 which defined details regarding functioning of the aforementioned network.

Five years after establishing the network, it turned out that fugitives were finding sanctuary in third countries more and more often. Following this revelation, a need for network expansion to non-EU member states was recognized. Competent organizational units of these countries have an observer status without voting rights. Nonetheless, this does not limit the possibility of cooperation. Recognisability of FAST teams is shown in the possibility of operative actions throughout the whole national territory. Special instruments are used by the teams when searching for fugitives, primarily those which allow, due to modern technologies, reliable locating, finding and arrest of fugitives. Cases dealt with by these units are mostly linked to perpetrators of serious crimes. Fast and efficient location of those perpetrators is the main goal. Special investigation techniques are used here, and the results of such measures may be used exclusively within the framework of performing search measures.

Table 2: Number of realised cases where requests for assistance in locating and arresting fugitives were submitted in the period from 20102016.

\begin{tabular}{|c|c|c|c|c|c|c|c|}
\hline Number of arrests & $\mathbf{2 0 1 0}$ & $\mathbf{2 0 1 1}$ & $\mathbf{2 0 1 2}$ & $\mathbf{2 0 1 3}$ & $\mathbf{2 0 1 4}$ & $\mathbf{2 0 1 5}$ & $\mathbf{2 0 1 6}$ \\
\hline Number of countries that requested the arrest & & 58 & 45 & 220 & 223 & 239 & 251 \\
\hline Number of countries in whose & & 11 & 7 & 22 & 22 & 27 & 27 \\
\hline territory the arrests were made & & 23 & 16 & 26 & 28 & 26 & \\
\hline
\end{tabular}

Source: European Network of Fugitive Active Search Teams statistical data (ENFAST). 
Justification of usage of the aforementioned measures can be confirmed on the basis of statistical data analysis on the success of FAST teams. (Table 2) shows the number of realized cases where a request for assistance in locating and apprehension of fugitives was submitted (number of cases which ended in arrest) for the period of 2010-2016. In 2010, after establishing the European
Network of Fast Active Search Teams, cooperation was realized in only three cases where all fugitives were arrested. During the years, the number of successfully closed cases increased rapidly and in 2016 it reached the number of 251 arrested fugitives in 30 countries upon the request of 27 members of ENFAST (Table 2).

Table 3: Types of crime for which fugitives were searched for in the period of 2013-2015.

\begin{tabular}{|c|c|c|c|}
\hline & 2013 & 2014 & 2015 \\
\hline Narcotic drugs abuse & 47 & 40 & 45 \\
\hline Organised property crime & 0 & 6 & 18 \\
\hline Tax frauds & 0 & 0 & 5 \\
\hline Economic crime & 39 & 49 & 17 \\
\hline Counterfeiting & 0 & 0 & 16 \\
\hline Homicides & 32 & 35 & 41 \\
\hline Grievous bodily injury & 11 & 15 & 41 \\
\hline Robberies & 35 & 27 & 26 \\
\hline Criminal offences against freedom & 11 & 9 & 14 \\
\hline Violent behaviour & 0 & 0 & 2 \\
\hline Trafficking in human beings & 3 & 3 & 4 \\
\hline Sex offences & 19 & 27 & 37 \\
\hline Extortions & 4 & 3 & 5 \\
\hline Criminal association & 6 & 3 & 4 \\
\hline Other criminal offences & 10 & 3 & 5 \\
\hline
\end{tabular}

Source: European Network of Fugitive Active Search Teams statistical data.

Based on presented data, we can conclude that the formation of national units working within an informal European network was a successful step forward. A significant increase was registered in the number of arrested persons on the basis of conducted joint operations. This has certainly made a positive impact on EU citizens' trust in the police and judicial institutions. As seen in (Table 3) wanted fugitives in the majority cases committed criminal offences in the area of drugs, economic crime related to organized crime groups and violent criminal offences (homicides, grievous bodily injuries) and sex offences.

\section{Fast Units Work Methodology}

As previously mentioned, in 2008 the Croatian police have established a unit specialized in active searching for the most prominent fugitives in the country and abroad, and in searching, further to a foreign country request, for fugitives hiding on the Croatian territory. Like other units in the world, the Croatian FAST uses cutting age technology and methodology to facilitate their work and raise their quality and success in locating and arresting wanted persons.

Alongside traditional search methods as the basic information-collecting tools, modern technology is also used, particularly special audio and video techniques, precise locating and collecting mobile devices' and Sim cards' identification numbers (IMEI and IMSI numbers), special evidence collection techniques, covert police activities and the like. When searching for fugitives the police collect information that can help locating them and information on other criminal offences. This second kind of information is forwarded to other competent units.

Unlike some other EU Member States, the Croatian legal framework is adequate and significantly facilitates locating and arresting fugitives. In the EU, there are substantial differences in the possibilities to use special investigation techniques when searching for persons, Austria and Germany allow for their use, but Slovenia and Hungary do not. In the region, Montenegro and Kosovo both have legislation allowing using special investigation techniques for that purpose.

Pursuant to Art. 332(7) of Croatian Criminal Procedures Act (cro. Zakon o kaznenom postupku) the special investigation technique of interception and technical recording of telephone conversations and other means of remote communication can be used on persons and telecommunication devices that are used to transmit information to fugitives or used by fugitives themselves. Further to that, please see an example of the successful implementation of this special investigation technique in Example 1.

\section{Example 1}

In 2009 a robbery was committed in Zagreb when armed perpetrators entered a Financial Agency (FINA) office and killed two security guards with automatic weapons. After the 
perpetrators had been identified, one of them (A.R.) fled. The Fugitive Unit was assigned the case in 2011, and at the time information suggested that A.R. was not hiding in Croatia. As a result of hard work and systematic collection of information, the Fugitive Unit was able to trace the countries where the fugitive was staying. However, A.R. was always one-step ahead of the investigators. Traces led to Bulgaria, Spain, Germany and finally Bosnia and Herzegovina, where the fugitive had been hiding since the beginning of 2014 .

A warrant was issued allowing special investigation techniques to be used on family members of the fugitive for a period of three months. During that period the fugitive was not successfully located. Later on the investigators learned that his best men had been helping him hide, and that the fugitive was possibly coming to Zagreb. Again, a warrant was issued allowing special investigation techniques to be used on I.K., the fugitive's best man. Monitoring his telephone conversations, a conversation was recorded between I.K. and A.R.'s lawyer arranging a meeting in an apartment in Zagreb that the fugitive's son was also to attend. After having established the exact location, an ambush was organized. The apartment was under surveillance and I. K., A.R.'s lawyer and A.R.'s son entered the apartment. After a while, food was delivered to the address. They ordered 4 servings. Using further undercover work it was established that the fugitive A.R. was in the same building, at the second floor. He was arrested.

Harmonization of the Croatian legal framework with the real needs in the fight against the most complex forms of crime and extremely resourceful criminals is evident in the ability of the police to ask from the provider of communication services to check the incidence, duration and frequency of communications with certain electronic communication addresses. This police power is called Obtaining phone records and is described in art. 68(1) of the Police Duties and Powers Act (cro. Zakon o policijskim poslovima i ovlastima). This tool is one of the basic and most commonly used tools in criminal investigations and locating fugitives. Phone records can be used to precisely define the relations between fugitives and persons helping them to hide, as described in Example 2. However, this procedure takes a long time and requires a systematic analytical approach. In cases that are more complex the assistance of specialist criminalintelligence analysts is sought.

\section{Example 2}

In 2016 the Split County Police Administration forwarded a request to search for Z.E., wanted for a number of frauds. They had the last known phone number used by Z.E. The number had not been used for a number of months. However, phone records analyze indicated some frequently contacted numbers. Based on further phone-records analyses the new number used by Z.E. was established. Later, using precise mobile devices location tools, the fugitive was located and arrested. Global positioning system-GPS (and Tracking device) is one of the most valuable tools used by law enforcement agencies. The legal basis is Croatia is Art. 80 of the Police Duties and Powers Act and Art. 120a of the Code of Practice of Police Officers (Pravilnik o načinu postupanja policijskih službenika). It is crucial to dispose of a large number of verified information before using GPS, thus making the use of this tool effective. Namely, when devices of this kind are used it is of the utmost importance to clearly define the goal and target of the action. It is also important to have information on possible aides and information providers keeping contact with the fugitive, i.e. the target person.

Moreover, working with GPS devices requires detailed planning of support, because the results provided by the device do not mean much.

They provide information on locations visited by the person suspected to be in contact with the fugitive. That is why operational field work is crucial, as information collected needs to be checked in real time.

New technologies have heavily influenced the automobile industry so GPS devices are being increasingly found in vehicles as standard equipment. Likewise, CCTV in public places has spread rapidly. Although this kind of surveillance sacrifices privacy, it raises the security level and acts as prevention of criminal offences. These tools are very useful in searching for fugitives, as described in Example 3.

\section{Example 3}

In 2015 the Split County Police Administration forwarded a request to locate and arrest three fugitives wanted for fraud. One was suspected to be hiding in the Zagreb area, because his girlfriend was staying there from time to time when working as a model for a number of fashion agencies. There were some indications that the two other fugitives could be also hiding in the Zagreb area. Police officers of the Fugitives Unit checked the above mentioned girlfriend. They established that the girl was filming a fashion show in the center of Zagreb. She was using a personal vehicle of a friend from Split. Investigators used GPS to determine the locations where the girl had been moving. After having analyzed the results, two locations were pointed out as places where she spent her free time. After a few days the investigators found all three of the fugitives at the addresses pointed out by the analysis. The fugitives were arrested. Being a global system, GPS is frequently used in international police cooperation. Moreover, it is used internationally whenever possible to locate fugitives, and is one of the most valuable tools, as demonstrated in Example 4.

\section{Example 4}

In 2015 the Germany Fugitive Unit sent a request to locate and arrest two persons wanted for murder. Available information indicated that the fugitives were located in west Zagreb. They were prominent members of a criminal organization. Although the reaction was quick and the German and Croatian colleagues 
communicated directly, the subjects were not apprehended immediately, but they were found leaving the Zagreb area in a car. German colleagues provided technical support tracking the factory-installed car GPS system. The fugitives were travelling in the direction of Split, but when they entered the city the signal was lost. As investigators were not sure if the fugitives were really located in the vehicle, they had to wait to recover GPS signal. After some hours, the vehicle was located again. By that time the vehicle was already in Gorica, Slovenia, near the Italian border.

The Slovenian FAST was immediately notified and in a trilateral arrangement, Slovenian police took over following the vehicle, but without taking any steps in arresting the fugitives. Communications interception showed that only one of the two fugitives was in the vehicle. The fugitives were supposed to meet in the next 24 hours. This information was corroborated by video surveillance from a restaurant in Gorica where the fugitive stopped. The fugitive using the vehicle continued to travel through Italy and entered Austria. The Austrian Fugitive Unit was informed, and the investigators were waiting for the moment when the fugitives will meet. When this happened, both fugitives were arrested.

The previous example perfectly illustrates that open borders facilitate the mobility of fugitives, and only a strong and direct connection of competent police authorities can achieve a successful result in the fight against international crime. Technology is a great help, but the human factor is key, not only well trained and motivated police officers, but also informants and information suppliers. Good quality operational information provided by a reliable source is crucial as it can steer the criminal investigation in the right direction and ensure its success.

Every person cooperating with the police has its own reasons for doing so. One of the greatest challenges in working with informants is to establish the real motives why someone is willing to cooperate and then to build a quality relationship of trust. When searching for persons the most sensitive part of the job is to find a reliable person that can provide information and is willing to do so. Finding a person like that takes a lot of time, months and even years. The last example shows the importance of working with informants when searching for fugitives.

\section{Example 5}

In 2010 Šibenik-Knin County Police Administration forwarded a request to locate and arrest a person wanted for war crime. The fugitive had previously been convicted but the appellate court annulled the verdict. He had no intention of participating to the repeated trial so he had been on the run for six years. When the search was initiated the investigators had no information on the places where the person might be hiding. They analyzed all available information and started collecting new information. During the search the investigators established that the subject was prone to conflicts with neighbors and friends, particularly when under the influence of alcohol.
Of all the person's the fugitive had contacts with when he was free, the investigators singled out one person. The fugitive owed the person a certain amount of money, causing the company of the person to go bankrupt. The person had an emotional attachment to the children of the fugitive. Police officers approached the potential information provider and, after a long period, they succeeded in building a relationship of trust. Later on, information collected pointing out that the fugitive might be located in Germany, and that he kept in touch with his wife and their three children.

The information provider confirmed these suspicions, and explained the way the fugitive provided mobile phone numbers and money to his family in Croatia. The investigators forwarded information to the German police and they started monitoring the fugitive's phone. A recording of his conversation was played to the information provider and he recognized the fugitive's voice and helped to additionally confirm the identity of the subject. In the next four hours the fugitive was located near Frankfurt and, after seven years, he was finally arrested.

\section{Conclusion}

Tackling transnational crime is one of the priorities of the European Union, and requires supranational models for successfully tackling it. It is therefore of the utmost importance to constantly adapt legislative frameworks and implement new national and international instruments. Some of the tools available in searching for fugitives are special investigation techniques. In Croatia they are not used enough for this purpose and great improvements could be made. However, most cases of cooperation with foreign police authorities have been successfully closed.

ENFAST was established to improve and harmonize the procedures of police authorities in different countries when searching for fugitives. Based on the results, it is fair to say that FAST and the European Network have justified their existence. Thanks to their efforts, searching, locating and arresting fugitives and handing them over to the judicial authorities has been increasingly successful. The use of innovative methods is of the utmost importance. The increasing success in locating fugitives has positive impacts on the state of security, and is providing a clear message that crime is not worth it. All of the above strengthens the confidence of citizens in the legal system.

It is possible to predict some trends in the area of searching for persons. Taking into consideration the geographical position of Croatia (open to third countries, long EU external borderprospective Schengen borders) and the fact that during the tourist season a large number of EU citizens come to Croatia (after abolishing border checks with Hungary and Slovenia, there will be no systematic controls) it is possible to foresee that some compensation measures will have to be adopted. There have to be considered technical possibilities provided by other systems, that can be used, under certain circumstances, by the police and other competent authorities, like EUVIS (database of 
visa requests containing information on persons, photographs and fingerprints) and EURODAC (database of asylum requests containing information on persons, photographs and fingerprints). Further to that, let it be noted that in 2018 SIS II is to be upgraded and it will contain fingerprints of all subjects.

When Croatia becomes full member of the Schengen area, all its borders to third countries will become EU external borders that have to be controlled systematically. This fact will have an effect on the increase of the workload of the police, both on borders and inside the state territory, and of the central unit for searching in SIS II (SIReNE section, International Police Cooperation Department). Moreover, at the moment, information is already being collected that will lead to locating and arresting a number of wanted fugitives. On the other hand, by introducing modern search methods and IT solutions and raising the efficiency of Croatian police, fugitives are beginning to avoid Croatia as a hiding place, and that should have a positive impact on the state of security.

\section{NOTES}

1. English acronym for Supplementary Information Request at National Entry.

2. In the Republic of Croatia the central organisational unit for coordination of operations in international searches is International Police Cooperation Department (INTERPOLEuropol-SIReNE) within the Criminal Police Directorate.

3. The European arrest warrant has been implemented in the Republic of Croatia since the day of its accession to the EU on 1 July 2013. Considerable number of arrests based on the EAW has been noticeable since 1 January 2014 when foreign EAWs started being implemented unconditionally to all Croatian citizens, but also due to increased transit and stay of foreigners in the Republic of Croatia, especially during the summer.

4. Input of this type of warning into the SIS II System is done by public and national security bodies.

5. Schengen Area currently includes 26 countries. They are 22 EU member states and Iceland, Lichtenstein, Norway and Switzerland. Bulgaria, Cyprus, Croatia and Romania are not a part of that area (those countries which did not fulfil accession conditions completely) and the UK and Ireland (they have special regime regarding access). The largeness of data in SIS II is presented by the following data: 70.9 million of entries, 3.9 billions of checks annually and more than 200000 hits.
6. Regulation (EU) 2016/399 as regards the reinforcement of checks against relevant databases at external borders (Official Journal of the European Union L 74/1 of 18 March 2017).

7. "Hit" refers to a positive result, i.e. located entry after conducting a search in SIS II. A concrete result means locating a wanted person or object towards which afterwards search measures can be applied.

8. Number of daily checks in the SIS II System for the period from 27 June till 31 July 2017 performed by Croatia was between $1,000,000$ to almost $1,300,000$. This number puts Croatia at the very top per number of checks, higher than those of much bigger Schengen Area members.

\section{References}

\section{Books}

1. Ivanda S (2001) Schengenski sporazumi i unutarnja sigurnost, Zagreb, MUP.

\section{Papers}

9. Hržina D, Rošić Mi, Stipišić Lj (2012) Postupci izručenja u Republici Hrvatskoj praktični aspekti Hrvatski ljetopis za kazneno pravo i praksu 19(2): 843-868.

10. Rakić M (2012) Uloga Eurojusta u sustavu pravosudne suradnje u kaznenim stvarima s državama članicama Europske unije. Policija i sigurnost 21(1): 132-142.

11. Rošić M (2014) Najznačajniji aspekti međunarodne policijske suradnje Republike Hrvatske s državama članicama Europske unije. Hrvatski ljetopis za kazneno pravo u praksu 21(2): 295-326.

\section{Laws and other normative acts}

1. Constitution of the Republic of Croatia, OG no. 56/90, 135/97, 08/98, 113/00, 124/00, 28/01, 41/01, 55/01, 76/10.

2. Act on Judicial Co-Operation in Criminal Matters with Member States of the European Union, OG no. 91/10, 81/13, 124/13, 26/15.

3. Act on Mutual Legal Assistance in Criminal Matters, OG no. 178/04.

4. Criminal Procedures Act, OG no. 152/08, 76/09, 80/11, 121/11, 91/12, 143/12, 56/13, 145/13, 152/14.Police Act, OG no. 34/11, $130 / 12,89 / 14,151 / 14,33 / 15,121 / 16$.

5. Police Act, OG no. 34/11, 130/12, 89/14, 151/14, 33/15, 121/16.

6. Police Duties and Powers Act, OG no. 76/09, 92/14.

7. Code of Practice of Police Officers, OG no. 89/2010.

8. ENFAST, Statement of Intent 2010.

\section{Internet sources}

1. Stojanovski SM, Stefanova BM (2016) New forms of international search of fugitives in the European Union and the Republic of Macedonia and use of special investigative measures.

2. Council Resolution on ENFAST (No. 15382/10 ENFOPOL 300 COPEN 233 CRIMORG 187) Brussels. 
CC (i) This work is licensed under Creative Commons Attribution 4.0 License DOI: $10.19080 /$ JFSCI.2017.04.555652

\section{Your next submission with Juniper Publishers will reach you the below assets}

- Quality Editorial service

- Swift Peer Review

- Reprints availability

- E-prints Service

- Manuscript Podcast for convenient understanding

- Global attainment for your research

- Manuscript accessibility in different formats ( Pdf, E-pub, Full Text, Audio)

- Unceasing customer service

Track the below URL for one-step submission https://juniperpublishers.com/online-submission.php 